H. 2992

ORNL/TM-6741

\title{
MASIER
}

\section{Simulated Fission Product Oxide Behavior In Triso-Coated HTGR Fuel}

\author{
R. L. Pearson \\ T. B. Lindemer
}

OAK RIDGE NATIONAL LABORATORY OPERATED BY UNION CARBIDE CORPORATION - FOR THE DEPARTMENT OF ENERGY 


\section{DISCLAIMER}

This report was prepared as an account of work sponsored by an agency of the United States Government. Neither the United States Government nor any agency Thereof, nor any of their employees, makes any warranty, express or implied, or assumes any legal liability or responsibility for the accuracy, completeness, or usefulness of any information, apparatus, product, or process disclosed, or represents that its use would not infringe privately owned rights. Reference herein to any specific commercial product, process, or service by trade name, trademark, manufacturer, or otherwise does not necessarily constitute or imply its endorsement, recommendation, or favoring by the United States Government or any agency thereof. The views and opinions of authors expressed herein do not necessarily state or reflect those of the United States Government or any agency thereof. 


\section{DISCLAIMER}

Portions of this document may be illegible in electronic image products. Images are produced from the best available original document. 


\section{Printed in the United States of America. Available from}

National Technical Information Service

U.S. Department of Commerce

5285 Port Royal Road, Springfield, Virginia 22161

Price: Printed Copy $\$ 4.50 ;$ Microfiche $\$ 3.00$

This report was prepared as an account of work sponsored by an agency of the United States Government. Neither the United States Government nor any agency thereof, nor any of their employees, contractors, subcontractors, or their employees, makes any warranty, express or implied, nor assumes any legal liability or responsibility for any third party's use or the results of such use of any information, apparatus, product or process disclosed in this report, nor represents that its use by such third party would not infringe privately owned rights. 
ORNL/TM-6741

Dist. Category UC-77

Contract No. W-7405-eng-26

CHEMICAL TECHNOLOGY DIVISION

HTGR BASE TECHNOLOGY PROGRAM

HTGR Chemistry Studies (189a 01329)

SIMULATED FISSION PRODUCT OXIDE BEHAVIOR

IN TRISO-COATED HTGR FUEL

R. L. Pearson and T. B. Lindemer

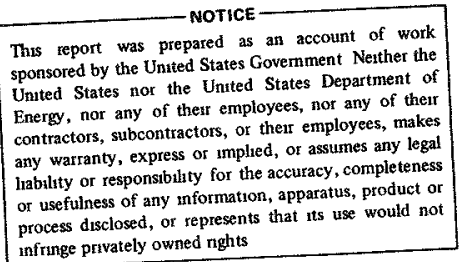

Date Published: August 1979

OAK RIDGE NATIONAI LABORATORY

oak Ridge, Tennessee 37830

operated by

UNION CARBIDE CORPORATION

for the

DEPARTMENT OF ENERGY 
ABSTRACT $\ldots \ldots \ldots \ldots \ldots \ldots \ldots \ldots \ldots \ldots \ldots \ldots \ldots \ldots \ldots \ldots \ldots \ldots \ldots \ldots \ldots \ldots \ldots$

1. INTRODUCTTON $\ldots \ldots \ldots \ldots \ldots \ldots \ldots \ldots \ldots \ldots \ldots \ldots \ldots \ldots \ldots \ldots \ldots \ldots \ldots \ldots$

2. EXPERIMENTAL PROCEDURE $\ldots \ldots \ldots \ldots \ldots \ldots \ldots \ldots \ldots \ldots \ldots \ldots \ldots \ldots$

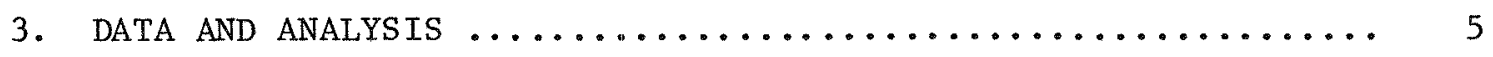

3.1 Oxides Containing Strontium and Zirconium .......... 5

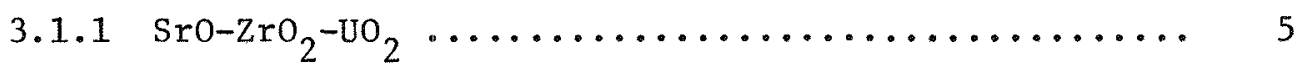

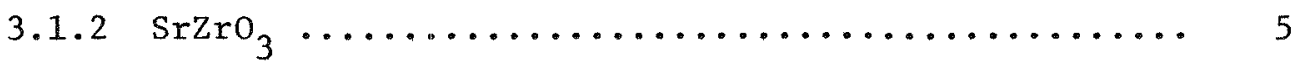

3.2 Rare Earth Oxides ........................ 8

3.3 Rare Earth Oxide and Rare Earth Carbide Mixture ....... 14

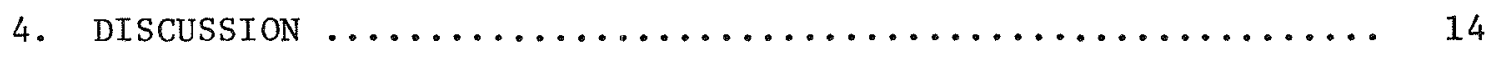

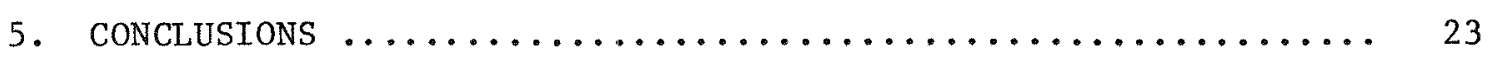

6. ACKNOWLEDGMENTS $\ldots \ldots \ldots \ldots \ldots \ldots \ldots \ldots \ldots \ldots \ldots \ldots \ldots \ldots \ldots \ldots \ldots$

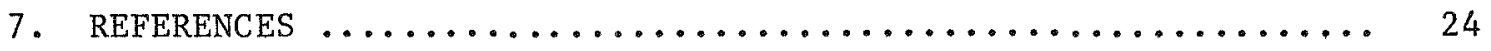


SIMULATED FISSION PRODUCT OXIDE BEHAVIOR

IN TRISO-COATED HTGR FUEL

R. L. Pearson and T. B. Lindemer

ABSTRACT

Several combinations of Triso-coated $\mathrm{UO}_{2}$ particles with additions of simulated Eission product oxides were investigated. They were first heat-treated in the 1aboratory; then their behavior was examined by metallography, radiography, the scanning electron microscope, and electron microprobe $x$-ray analysis. Pressures of the various gaseous species within the particles were calculated and displayed as Ellingham diagrams. It appears to be essential that Trisocoated fuel have impermeable inner high-density pyrocarbon (iLTI) layers, because the fission product strontium, in gaseous form, will interact with SiC. As oxides, the rare earth fission products redistributed slightly within the buffer layer but did not interact with the SiC layers.

\section{INTRODUCTION}

One of the main purposes of a SiC layer in HTGR Triso*-coated fuel. particles is to serve as a barrier to prevent release of the metallic fission products. ${ }^{1}$ Without it, many of the fission products would diffuse through the Bisot coating of the fuel particles ${ }^{2}$ and eventually enter the primary circuit, creating a maintenance and safety hazard. Several years ago, during a postirradiation study of the behavior of metallic fission products in Triso-coated $\mathrm{UO}_{2}$ fuel, it was noticed that the SiC layer had been attacked, and it was proposed that the attacking

* Triso is a particle-coating design consisting of a low-density pyrocarbon buffer layer, an inner high-density pyrocarbon layer (iLTI), a SiC layer, and an outer high-density pyrocarbon layer (oLTI).

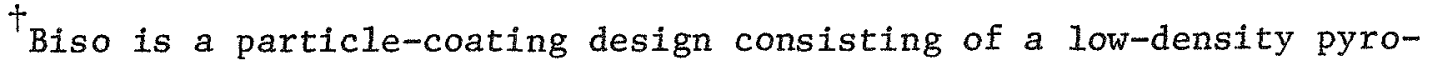
carbon buffer layer adjacent to the kernel covered by a high-density pyrocarbon layer. 
fission product was strontium. ${ }^{3}$ At about the same time, postirradiation examination of a thermal gradient annealing test of $93 \%$ enriched Trisocoated $\mathrm{UC}_{2}$ revealed that some of the fission products had migrated down the temperature gradient to the SiC layer. In some cases there was interaction with the SiC. ${ }^{4}$ Electron microprobe analysis of the interaction zone revealed the presence of $\mathrm{La}, \mathrm{Ce}, \mathrm{Pr}, \mathrm{Nd}, \mathrm{Sm}$, and $\mathrm{Eu},{ }^{4,5}$ These are the most abundant rare earth fission products (Table 1). ${ }^{6}$ It appears from these tests that interaction may occur between SiC and several fission products that exist in a specific chemical form. We have previously investigated the extent of interaction of several rare earth carbide kernels with SiC in Triso-coated particles. ${ }^{7}$ The purpose of this paper is to study the behavior of several simulated fission product oxides in Triso-coated particles.

Table 1. Yield summary for fission products of interest (based on 100 fissions at thermal neutron-energy)

\begin{tabular}{lrrrr}
\hline & ${ }^{233} \mathrm{U}$ & ${ }^{235} \mathrm{U}$ & ${ }^{239} \mathrm{Pu}$ & ${ }^{241} \mathrm{Pu}$ \\
\hline $\mathrm{Sr}$ & 12.378 & 9.565 & 3.481 & 2.627 \\
$\mathrm{Zr}$ & 32.612 & 31.040 & 18.876 & 15.743 \\
$\mathrm{Ba}$ & 6.008 & 6.770 & 6.144 & 6.859 \\
$\mathrm{La}$ & 6.311 & 6.385 & 5.681 & 5.881 \\
$\mathrm{Ce}$ & 13.114 & 12.183 & 10.566 & 11.385 \\
$\mathrm{Pr}$ & 6.536 & 5.838 & 5.289 & 5.028 \\
$\mathrm{Nd}$ & 18.182 & 20.640 & 16.217 & 18.781 \\
$\mathrm{Pm}$ & 1.710 & 2.229 & 2.050 & 2.392 \\
$\mathrm{Sm}$ & 1.327 & 1.833 & 2.883 & 3.671 \\
$\mathrm{Eu}$ & 0.125 & 0.193 & 0.535 & 0.800 \\
$\mathrm{Gd}$ & 0.019 & 0.022 & 0.245 & 0.423 \\
$\mathrm{~Tb}$ & 0.001 & 0.001 & 0.021 & 0.049 \\
\hline
\end{tabular}




\section{EXPERIMENTAL PROCEDURE}

The Triso-coated particles used in this study contained either Sro$\mathrm{ZrO}_{2}-\mathrm{UO}_{2}, \mathrm{SrZrO}_{3}, \mathrm{La}_{2} \mathrm{O}_{3}, \mathrm{La}_{2} \mathrm{O}_{3}-\mathrm{LaC}_{2}, \mathrm{Nd}_{2} \mathrm{O}_{3}-\mathrm{UO}_{2}, \mathrm{Nd}_{2} \mathrm{O}_{3}-\mathrm{UO}_{2}-\mathrm{UC}_{2}$, or $\mathrm{Sm}_{2} \mathrm{O}_{3}$ kernels. The oxides of the $\mathrm{Sr}-\mathrm{Zr}-\mathrm{U}$ mix were made by heating oxalates coprecipitated from nitrate solution. ${ }^{8}$ The concentrations of strontium and zirconium were equal to the fission yields of strontium plus barium and of zirconium, respectively, in a medium-enriched fuel $\left(80 \%{ }^{238} \mathrm{U} ; 20 \%\right.$ $\left.{ }^{235} \mathrm{U}\right)$ irradiated to $20 \%$ FIMA. ${ }^{*}$ The resulting mixture was 1.5 wt $\%$ Sro, $3.3 \mathrm{wt} \% \mathrm{ZrO}_{2}$, and 95.2 wt $\% \mathrm{UO}_{2} \cdot \mathrm{SrZrO}_{3}$ was purchased from Alpha Products of Danvers, Massachusetts. These powders were hot-pressed, and the desired kernel sizes were obtained by crushing and sieving the pellets. Kernels of $\mathrm{La}_{2} \mathrm{O}_{3}, \mathrm{Sm}_{2} \mathrm{O}_{3}$, and the mixture of $\mathrm{Nd}_{2} \mathrm{O}_{3}-\mathrm{UO}_{2}$ were prepared by loading a weak-acid resin (WAR-Amberlite IRC-72) with the appropriate cations from an acid-deficient nitrate solution. ${ }^{9,10}$ The carbonizing and partial conversion of the loaded resin to a carbide was carried out under controlled conditions. 11 Each batch of kernels was Triso-coated, except

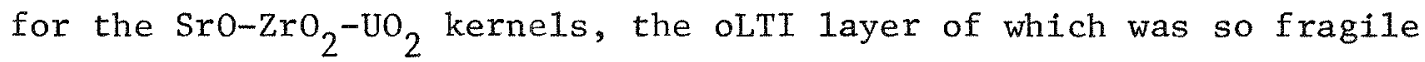
that it did not remain in place. Descriptions of the completed oxide and oxide-carbide particles are found in Table 2.

Attempts to determine the composition of the resin-loaded oxides or oxide-carbide by Debye-Scherrer x-ray patterns were unsuccessfu1. The patterns were too diffuse to analyze, probably because the crystallites in either the "as made" or the $2173 \mathrm{~K}$ heat-treated WAR particles were too small. From the x-ray pattern obtained with a scanning electron microscope (SEM), we estimated that $95 \%$ of the $\mathrm{Nd}_{2} \mathrm{O}_{3}-\mathrm{UO}_{2}$ mixture was $\mathrm{UO}_{2}$. Extended hot chlorine leach tests, ${ }^{12}$ performed prior to application of the SiC layer, revealed that all of the batches listed in Table 2 had impermeable iLTI layers, except for the $\mathrm{SrzrO}_{3}$ particles. This conclusion was drawn because no change could be observed in radiographs taken before and after an 18-hr chlorine treatment at $1773 \mathrm{~K}$ and because no chlorine was detected in the SEM $\mathrm{x}$-ray patterns of the completed particles. However, $5 \%$ of the $\mathrm{SrZrO}_{3}$ kernels was removed after the chlorine treatment.

*FIMA - Fissions per Initial Heavy Metal Atoms. 
Table 2. Characterization of particles containing simulated fission product oxides for use in SiC interaction studies

\begin{tabular}{|c|c|c|c|c|c|c|}
\hline $\begin{array}{l}\text { Kernel } \\
\text { composition }\end{array}$ & Batch No. & $\begin{array}{l}\text { Kernel } \\
\text { diameter } \\
(\mu \mathrm{m})\end{array}$ & $\begin{array}{c}\text { Buffer } \\
\text { thickness } \\
(\mu \mathrm{m})\end{array}$ & $\begin{array}{l}\text { iLTI }^{\mathrm{a}} \\
\text { thickness } \\
\quad(\mu \mathrm{m})\end{array}$ & $\begin{array}{c}\text { SiC } \\
\text { thickness } \\
(\mu \mathrm{m})\end{array}$ & $\begin{array}{l}\text { oLTI }^{b} \\
\text { thickness } \\
\quad(\mu \mathrm{m})\end{array}$ \\
\hline $\mathrm{SrO}-\mathrm{ZrO}-\mathrm{UO}_{2}$ & $O R-2770$ & $354-420$ & 114 & 86 & 59 & \\
\hline $\mathrm{SrZrO}_{3}$ & OR-2771 & $354-420$ & 62 & 44 & 43 & 98 \\
\hline $\mathrm{La}_{2}{ }^{\mathrm{O}} 3$ & $O R-2700$ & 340 & 44 & 48 & 33 & 50 \\
\hline $\mathrm{La}_{2} \mathrm{O}_{3}-\mathrm{LaC}_{2}$ & OR-2699 & 340 & 66 & 64 & 42 & 39 \\
\hline $\mathrm{Nd}_{2} \mathrm{O}_{3}-\mathrm{UO}$ & OR-2696 & 440 & 121 & 45 & 41 & 41 \\
\hline $\mathrm{Nd}_{2} \mathrm{O}_{3}-\mathrm{UO}_{2}-\mathrm{UC}_{2}$ & OR-2697 & 440 & 164 & 33 & 32 & 45 \\
\hline $\mathrm{Sm}_{2} \mathrm{O}_{3}$ & OR-2698 & 385 & 23 & 34 & 25 & 38 \\
\hline
\end{tabular}

$\mathrm{a}_{\text {iLTI }}=$ inner high-density pyrocarbon layer.

$b_{\text {oLTI }}=$ outer high-density pyrocarbon layer . 
About 25 particles from each batch were enclosed at midplane of a 1.25-cm-diam carbon disk and heat-treated in a graphite-resistance furnace in which a known temperature and temperature gradient of $278 \mathrm{~K} / \mathrm{cm}$ was maintained. The details of the procedure used to prepare particles for heat treatment have been published previously. ${ }^{13}$ The SiC thinning, if any, was determined from radiographs or from photomicrographs of the particles polished to midplane. Heavy metal movement within the Trisocoated particles was followed by $x$-ray analysis using radiography and/or the SEM.

\section{DATA AND ANALYSIS}

\subsection{Oxides Containing Strontium and Zirconium}

\section{$3.1 .1 \mathrm{SrO}-\mathrm{ZrO}_{2}-\mathrm{UO}_{2}$}

A carbon disk containing Triso-coated kernels of $\mathrm{SrO}-\mathrm{ZrO}_{2}-\mathrm{UO}_{2}$ was heat-treated at $1910 \mathrm{~K} \leq \mathrm{T} \leq 2200 \mathrm{~K}$ in a temperature gradient of $278 \mathrm{~K} / \mathrm{cm}$. Figure 1 is a composite of photographs showing results obtained after a 94-hr heat treatment. The interior of a typical strontium-containing Triso-coated particle is seen in the optical micrograph (Fig. 1c) of a polished particle. No $\mathrm{Sr}, \mathrm{Zr}$, or $\mathrm{U}$ movement from the kernel during heat treatment can be detected in either the radiographs (Fig. 1b) or by SEM $x$-ray analysis (Fig. 1d), nor can interaction be seen at the highly magnified interface (Fig. le). A second disk containing Triso-coated $\mathrm{SrO}-\mathrm{ZrO}_{2}-\mathrm{UO}_{2}$ was heated under identical conditions for $364 \mathrm{hr}$. Again, no interaction was observed in a radiograph. The limit of detection of SiC interaction in a radiograph is 2 to $3 \mu \mathrm{m}$; therefore, the maximum possible rate of SiC thinning in this sample would be $8.25 \times 10^{-3} \mu \mathrm{m} / \mathrm{hr}$. The point is plotted in Fig. 2 .

\section{$3.1 .2 \mathrm{SrZrO}_{3}$}

A carbon disk containing Triso-coated kernels of $\mathrm{SrZrO}_{3}$ was included in the run described in Sect. 3.1.1. After $94 \mathrm{hr}$ of heat treatment, no kerne1-SiC interaction was evident in the radiographs. The disk was then polished until the particles reached midplane. Several of the particles 


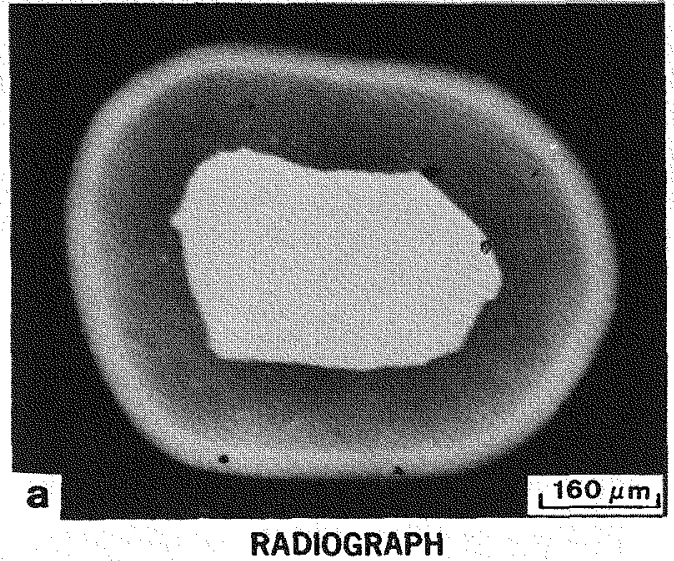

$\mathrm{O} \mathrm{hr}$

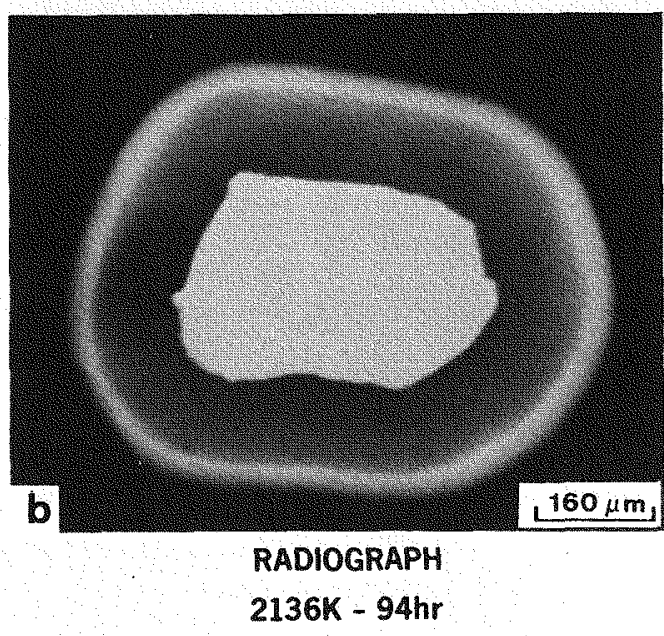

2136K - 94hr

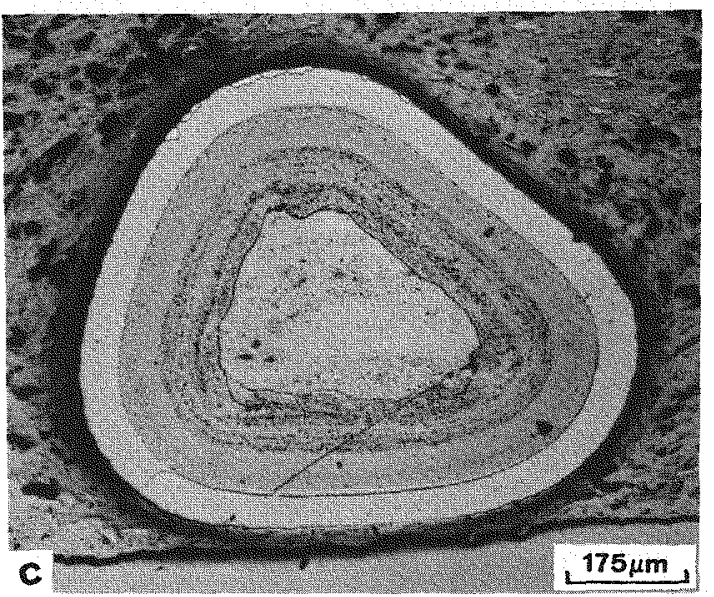

OPTICAL MICROGRAPH

$1951 \mathrm{~K}-94 \mathrm{hr}$

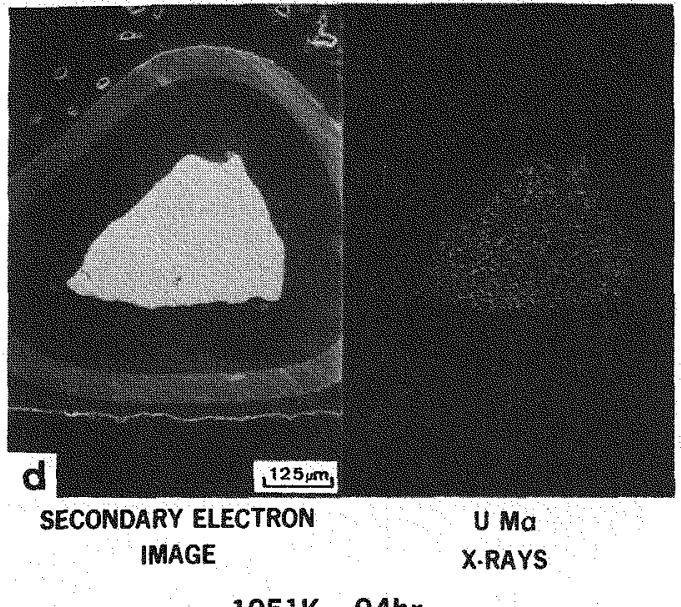

$1951 \mathrm{~K}-94 \mathrm{hr}$

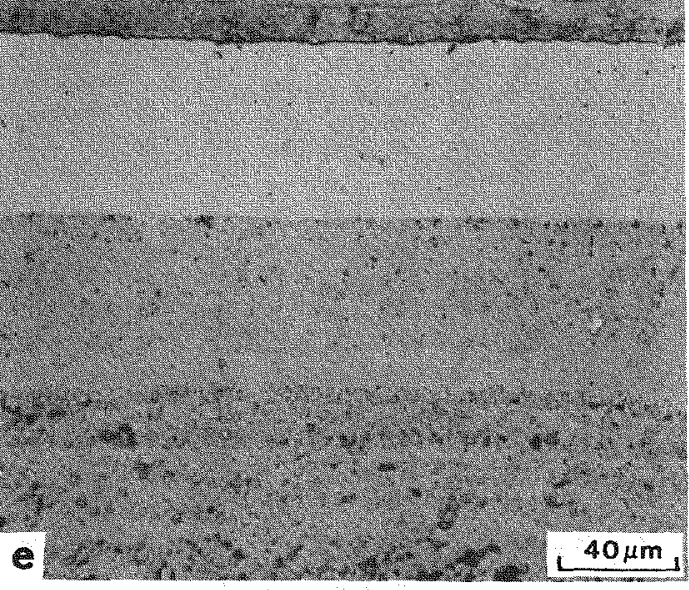

OPTICAL MICROGRAPH

$1951 \mathrm{~K}-94 \mathrm{hr}$

Fig. 1. Photographic results of Triso-coated $\mathrm{SrO}-\mathrm{ZrO}_{2}-\mathrm{UO}_{2}$ particles before and after heat treatment at 1951 and $2136 \mathrm{~K}$ for $94 \mathrm{hr}$ in a temperature gradient of $278 \mathrm{~K} / \mathrm{cm}$. Photographs a, $b$, and $c$ are mounted so that the cold side of the particle faces the left side of the page; the cold side in photograph $d$ faces the right side of the page. 


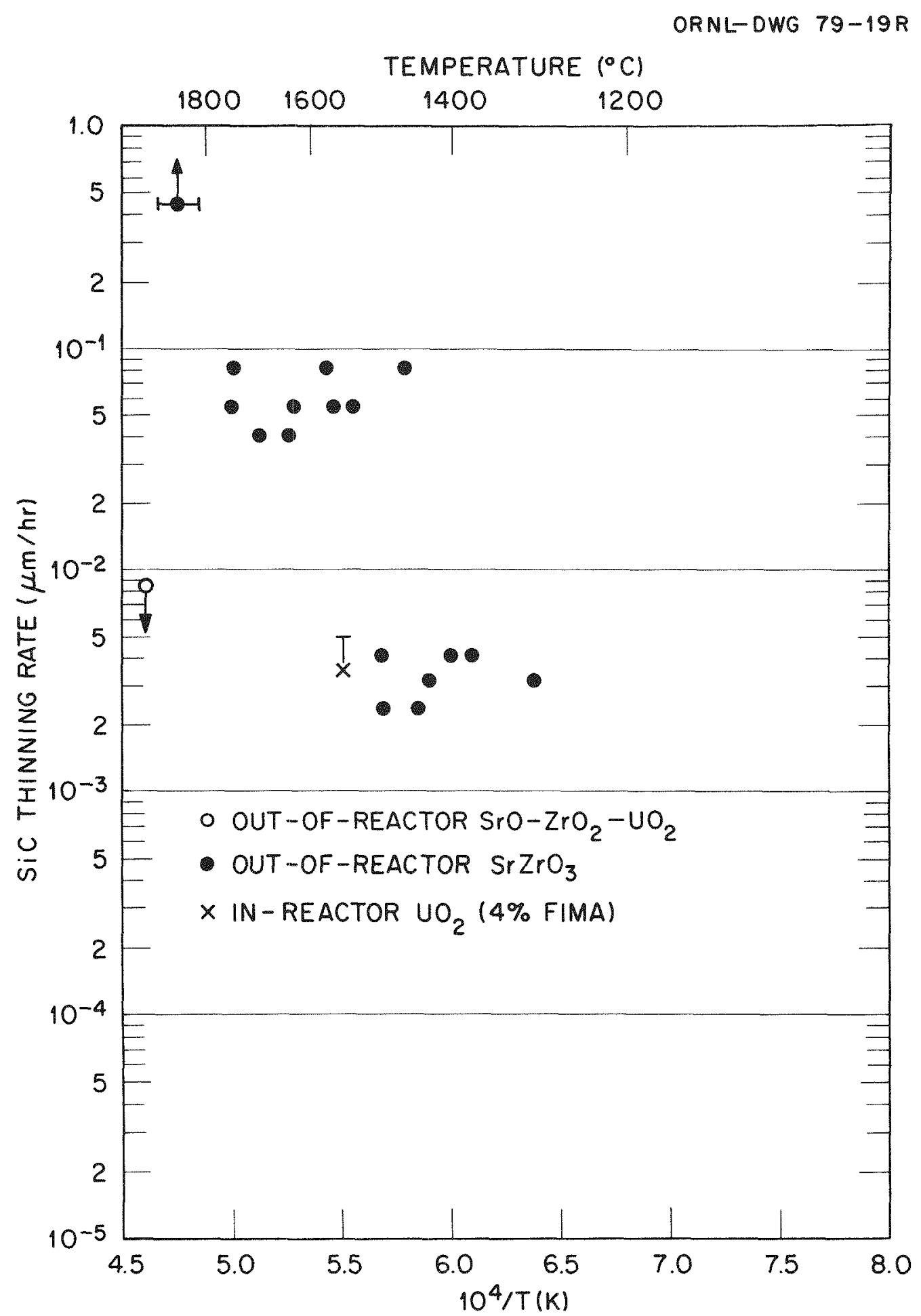

Fig. 2. Thinning rate of $\mathrm{SiC}$ for Triso-coated $\mathrm{SrO}-\mathrm{ZrO}_{2}-\mathrm{UO}_{2}$ and $\mathrm{SrZrO}_{3}$ particles in a temperature gradient of $278 \mathrm{~K} / \mathrm{cm}$ vs reciprocal temperature. Also shown $(x)$ is an estimate of the SiC thinning rate of a Triso-coated Uo, particle irradiated to 4\% FIMA (ref. 3). 
showed localized areas where complete penetration of the SiC had occurred (Fig. 3a). Each of the interaction points was at the end of a crack that led from the kernel through the carbon layers to the SiC. Microprobe examination of the interior and the interaction zone of these particles found both strontium and zirconium in the kernels, but only zirconium in the SiC breach area. A second run in the same temperature gradient, but held at a lower temperature (1725 to $2023 \mathrm{~K}$ ) for $260 \mathrm{hr}$, resulted in several points at which interaction occurred (Fig. 3b). Again, all the interaction zones were at the ends of cracks leading from the kernel through the carbon layers to the SiC layer. At these lower temperatures, the SiC was not breached but, instead, had been penetrated to approximately midpoint. A third run in the same temperature gradient, but held at 1473 to $1773 \mathrm{~K}$ for $3528 \mathrm{hr}$, showed some $\mathrm{SiC}$ interaction at the end of each crack leading from the kernel to the SiC layer (Fig. 3c). The thinning-rate data as a function of temperature are plotted in Fig. 2 .

\subsection{Rare Earth Oxides}

Carbon disks containing Triso-coated particles of either $\mathrm{La}_{2} \mathrm{O}_{3}$, $\mathrm{Nd}_{2} \mathrm{O}_{3}-\mathrm{UO}_{2}, \mathrm{Nd}_{2} \mathrm{O}_{3}-\mathrm{UO}_{2}-\mathrm{UC}_{2}$, or $\mathrm{Sm}_{2} \mathrm{O}_{3}$ were heat-treated at $1850 \mathrm{~K} \leq \mathrm{T} \leq$ $2175 \mathrm{~K}$ in a temperature gradient of $278 \mathrm{~K} / \mathrm{cm}$. The $\mathrm{La}_{2} \mathrm{O}_{3}$ wafer was removed from the holder after $232 \mathrm{hr}$, and the $\mathrm{Nd}_{2} \mathrm{O}_{3}-\mathrm{UO}_{2}, \mathrm{Nd}_{2} \mathrm{O}_{3}-\mathrm{UO}_{2}-\mathrm{UC}_{2}$, and $\mathrm{Sm}_{2} \mathrm{O}_{3}$ wafers were removed after $581 \mathrm{hr}$. Figures 4, 5, 6, and 7 are composite photographs used to analyze their behavior during heat treatment. Figure 4a, a radiograph of an "as made" Triso-coated La ${ }_{2} \mathrm{O}_{3}$ particle, is typical of all the WAR Triso-coated rare earth oxide particles. The spherical kernel is surrounded first by carbon layers devoid of any heavy metals and then by an outer SiC layer. The radiographs in Figs. 4, 5, 6, and 7 show that part of the heavy metals in each kernel had relocated within the inner carbon layers during heat treatment. As shown in Fig. 4b and $d$, some of the $\mathrm{La}_{2} \mathrm{O}_{3}$ had deposited within the buffer layer and at the iLII-buffer layer interface. Figure $5 \mathrm{~b}$ and $\mathrm{d}$ shows that some of the uranium had moved from the $\mathrm{Nd}_{2} \mathrm{O}_{3}-\mathrm{UO}_{2}$ kernel into the buffer layer on the cold side of the particle. There is more extensive movement of uranium in the $\mathrm{Nd}_{2} \mathrm{O}_{3}-\mathrm{UO}_{2}-\mathrm{UC}_{2}$ particle, as shown in $\mathrm{Fig}$. $6 \mathrm{a}$ and $\mathrm{b}$. The kernel 


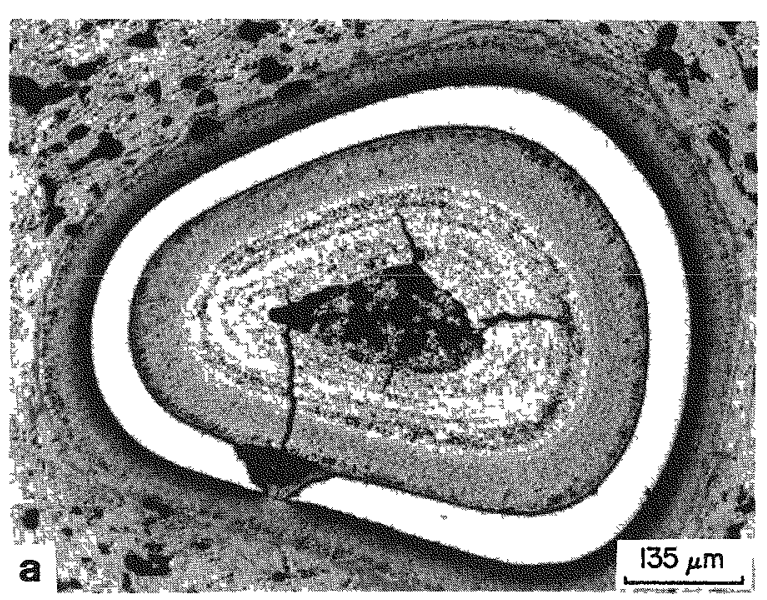

$2043 \mathrm{~K}-94 \mathrm{hr}$

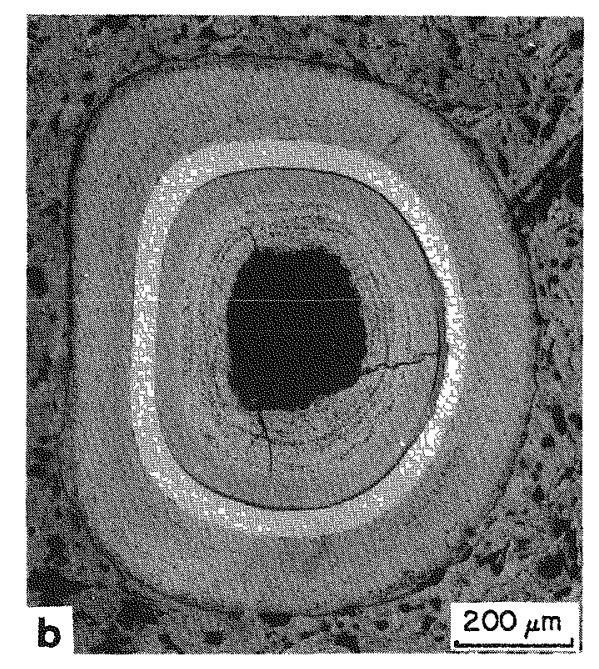

$1800 \mathrm{~K}-260 \mathrm{hr}$

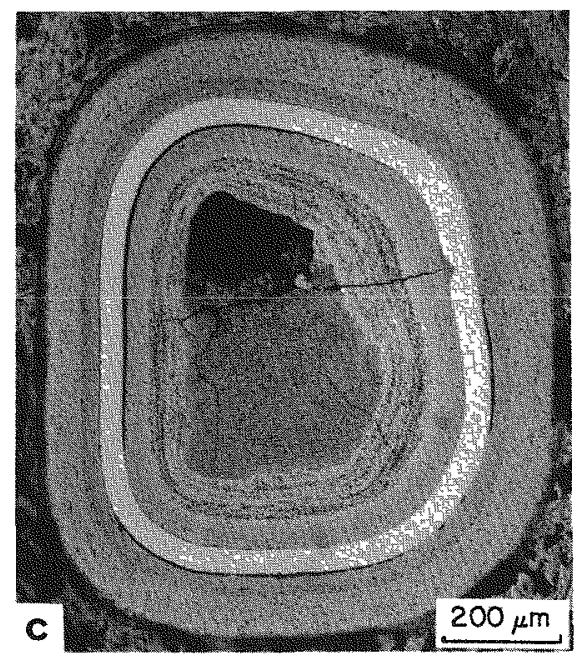

$1645 \mathrm{~K}-3528 \mathrm{hr}$

Fig. 3. Photomicrographs of Triso-coated $\mathrm{SrZrO}_{3}$ particles that have been heat-treated at $2050 \mathrm{~K}$ for $94 \mathrm{hr}, 1800 \mathrm{~K}$ for $260 \mathrm{hr}$, and $1645 \mathrm{~K}$ for $3528 \mathrm{hr}$ in a temperature gradient of $278 \mathrm{k} / \mathrm{cm}$. Photographs are mounted so that the cold side of the particle faces the top of the page. Note that each interaction occurs at the end of a crack leading from the kernel to the Sic layer. 


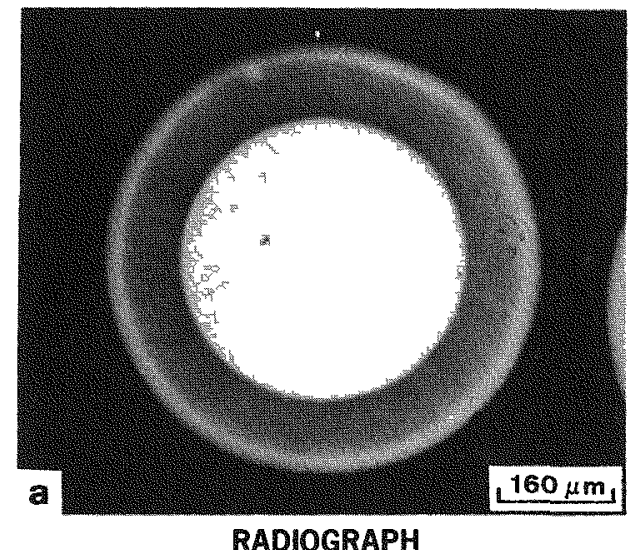

RADIOGRAP

O hr

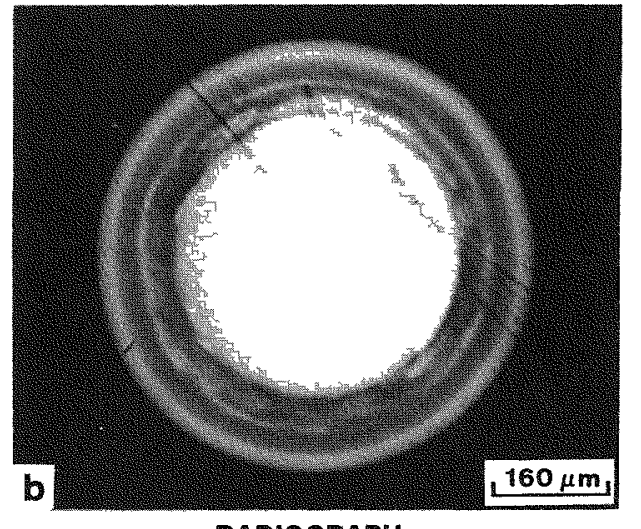

RADIOGRAPH

$1867 \mathrm{~K}-232 \mathrm{hr}$
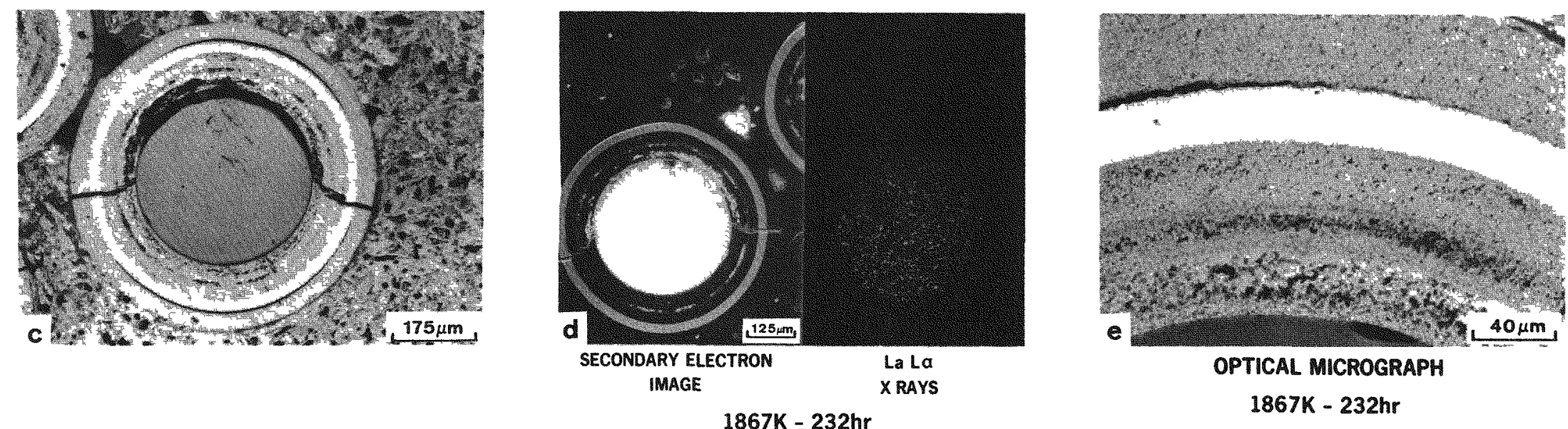

Fig. 4. Photographic results for a Triso-coated $\mathrm{La}_{2} \mathrm{O}_{3}$ particle after heat treatment at $2134 \mathrm{~K}$ for $232 \mathrm{hr}$ in a temperature gradient of $278 \mathrm{~K} / \mathrm{cm}$. Photographs are mounted so that the cold side of the particle faces the top of the page. Note that the lanthanum redistribution was only within the buffer layer. 
$Y 159251$

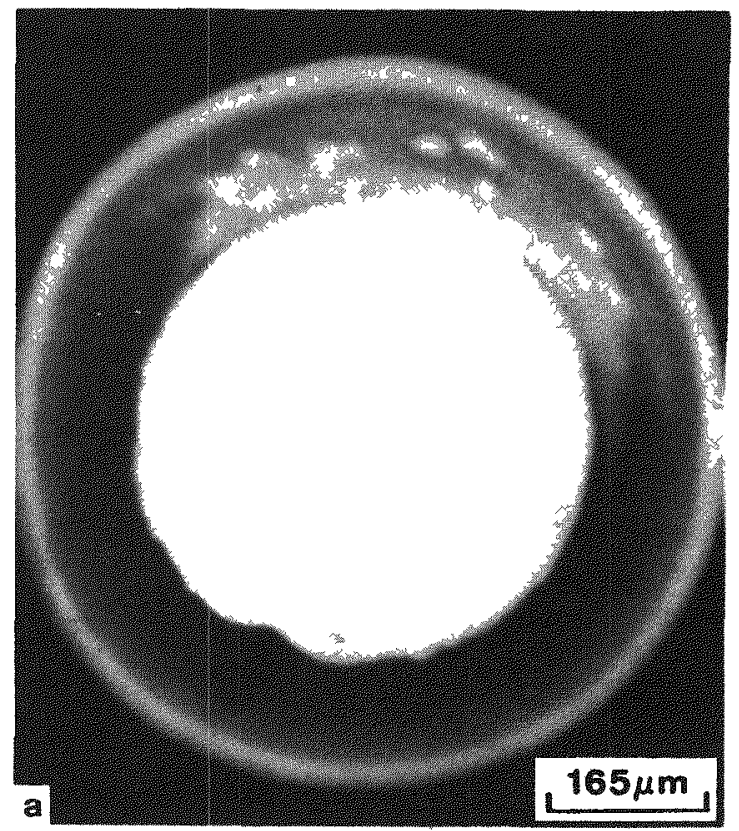

RADIOGRAPH

$2134 \mathrm{~K}$ - $581 \mathrm{hr}$

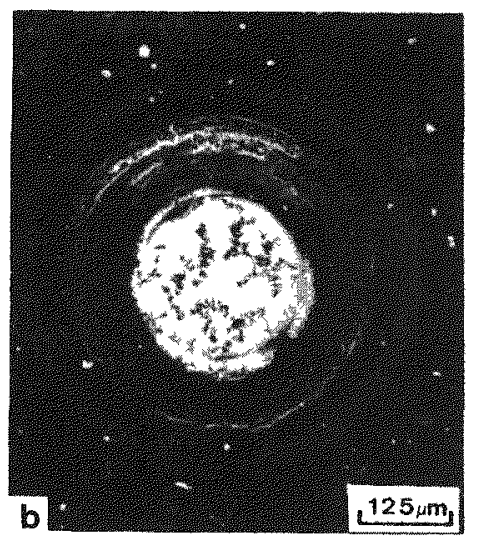

SECONDARY ELECTRON IMAGE

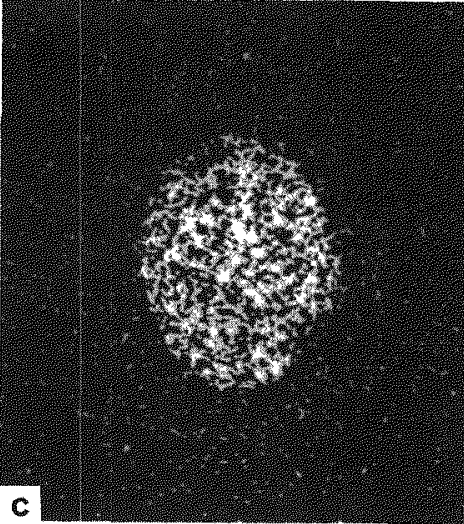

$\mathrm{Nd} \mathrm{La}$

X-RAYS

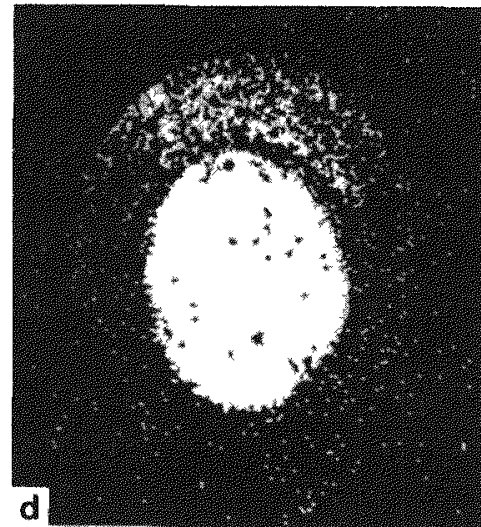

U Ma

X.RAYS

\section{$2134 K-581 h r$}

Fig. 5. Photographic results for a Triso-coated $\mathrm{Nd}_{2} \mathrm{O}_{3}-\mathrm{UO}_{2}$ particle after heat treatment at $2134 \mathrm{~K}$ for $581 \mathrm{hr}$ in a temperature gradient of $278 \mathrm{~K} / \mathrm{cm}$. Photographs are mounted so that the cold side of the particle faces the top of the page. Note that there was some redistribution of the uranium within the buffer layer at the cold end of the particle. 

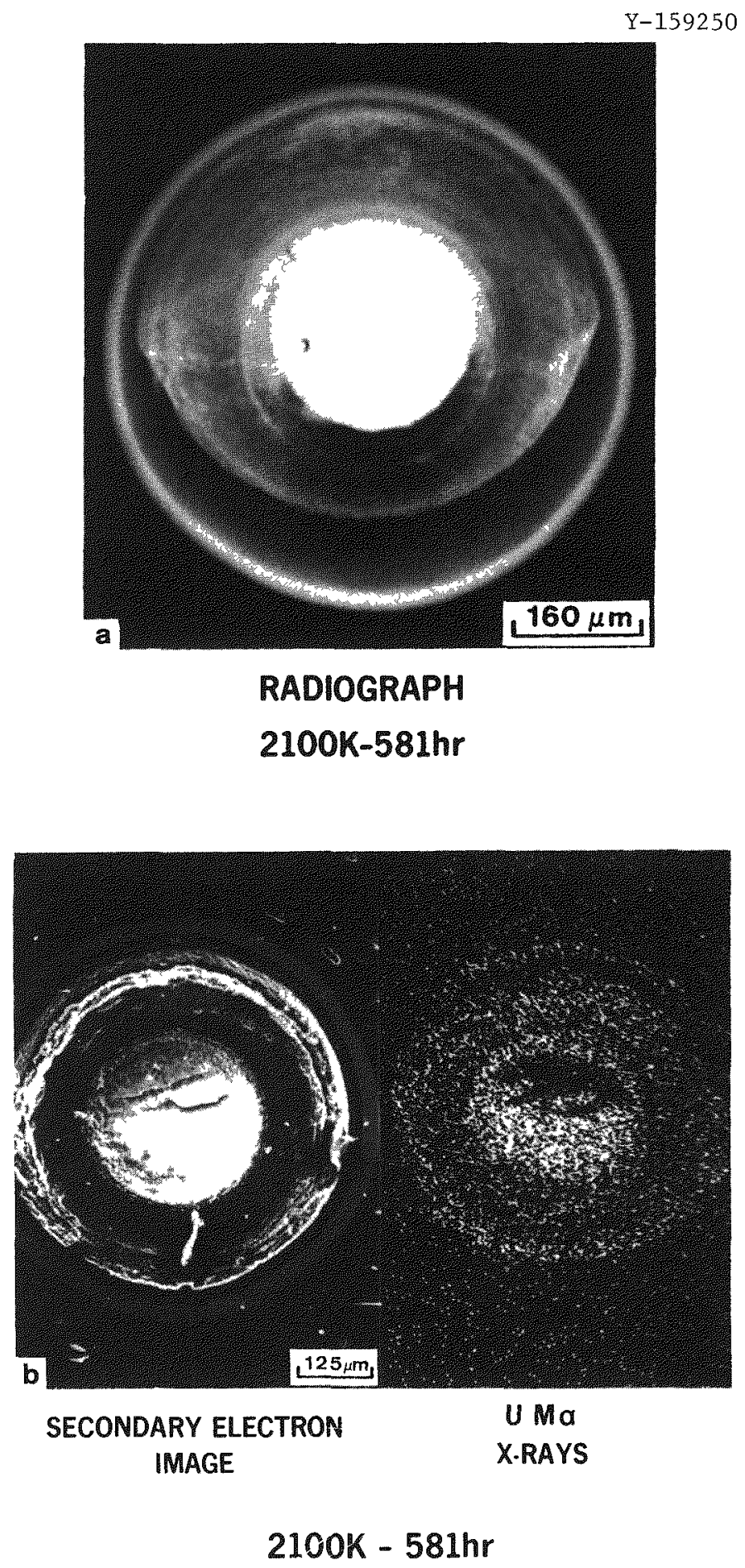

Fig. 6. Photograpinic results for a Triso-coated $\mathrm{Nd}_{2} \mathrm{O}_{3}-\mathrm{UO}_{2}-\mathrm{UC}_{2}$ particle after heat treatment at $2100 \mathrm{~K}$ for $581 \mathrm{hr}$ in a temperature gradient of $278 \mathrm{~K} / \mathrm{cm}$. Photographs are mounted so that the cold side of the particle faces the top of the page. Note that the kernel has shrunk and is off-center. Uranium has redistributed toward the cold side of the particle and appears to have entered the iLTI layer. 


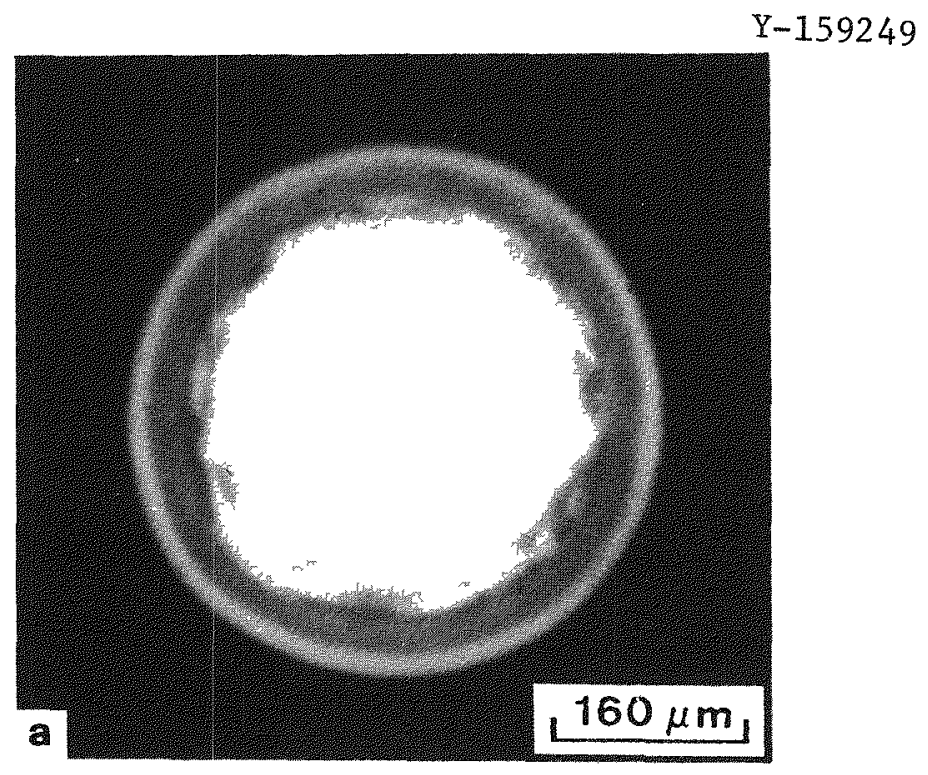

\section{RADIOGRAPH}

\section{K - 232hr}

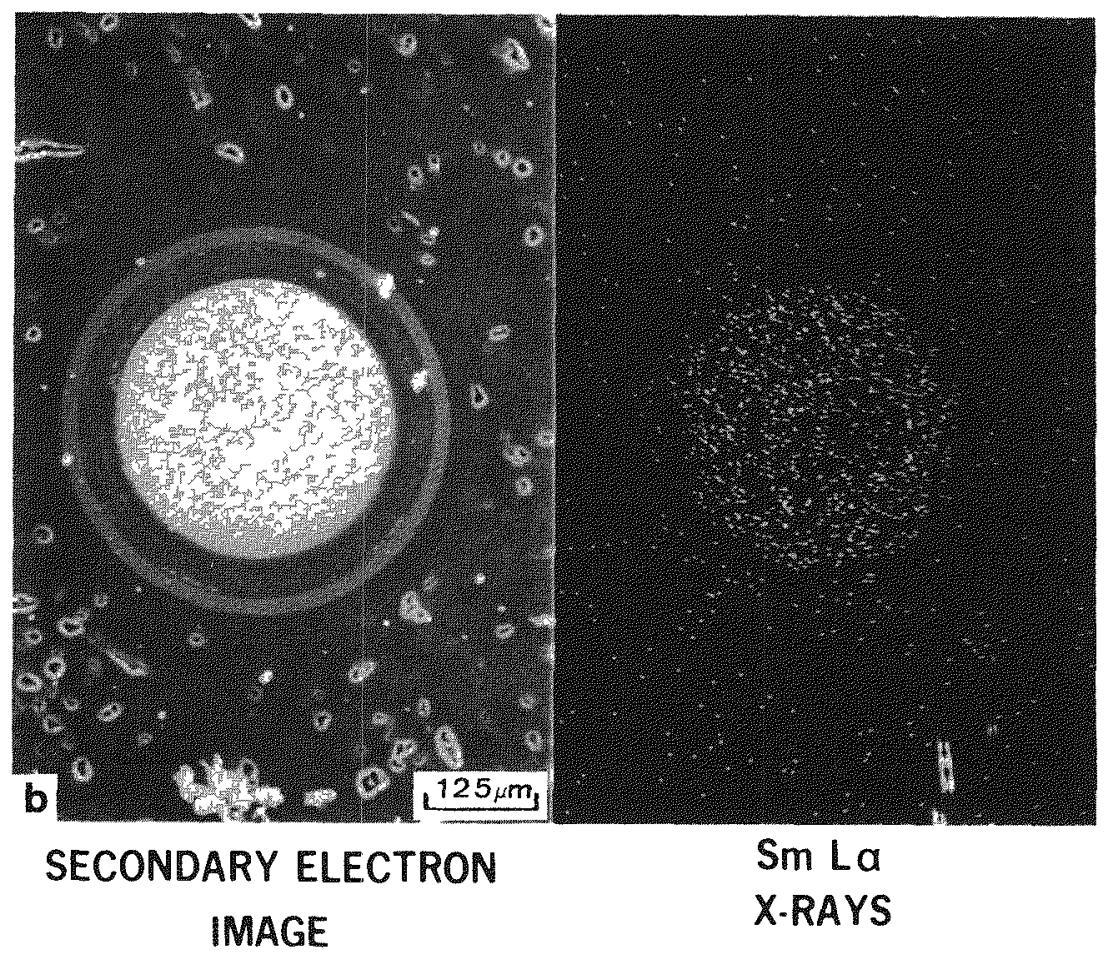

\section{K - 581hr}

Fig. 7. Photographic results for Triso-coated $\mathrm{Sm}_{2} \mathrm{O}_{3}$ particles after heat treatment at $1918 \mathrm{~K}$ for $581 \mathrm{hr}$ and $2094 \mathrm{~K}$ for $232 \mathrm{hr}$ in a temperature gradient of $278 \mathrm{k} / \mathrm{cm}$. Photographs are mounted so that the cold side of the particle faces the top of the page. 
appears to have shrunk and is off-center. An outline of the original kernel diameter is visible in the radiograph. This phenomenon is reminiscent of radiographs of heat-treated, Biso-coated $\mathrm{UO}_{2}-\mathrm{UC}_{2}$ particles. 14 The uranium movement is more extensive than it was in the $\mathrm{Nd}_{2} \mathrm{O}_{3}-\mathrm{UO}_{2}$ particles. Not only has some of it moved into the buffer layer, but it looks as though some uranium is in the IITI layer. Metallographic examination of a11 the heat-treated rare earth oxide particles revealed that none of the SiC layers had been damaged (Fig. 4c and e).

\subsection{Rare Earth Oxide and Rare Earth Carbide Mixture}

A carbon disk was filled with Triso-coated $\mathrm{LaC}_{2}-\mathrm{La}_{2} \mathrm{O}_{3}$ particles and heat-treated at $1850 \mathrm{~K} \leq \mathrm{T} \leq 2175 \mathrm{~K}$ in a temperature gradient of $278 \mathrm{~K} / \mathrm{cm}$. Radiographs were taken after $41 \mathrm{hr}$. A typical SiC-La interaction is shown in Fig. 8c. The penetration depth is approximately $12 \mu \mathrm{m}$. Both the radiograph (Fig. 8a) and the SEM x-ray photographs (Fig. 8b) verify that there has been lanthanum movement to the cold side of the particle. In comparing Figs. 4 and 8 , it becomes evident that lanthanum has reached the SiC-iLTI interface in the $\mathrm{La}_{2} \mathrm{O}_{3}-\mathrm{LaC}_{2}$ particles, where it can interact with the $\mathrm{SiC}$ layer. The SiC thinning rate as a function of $1 / \mathrm{T}$ for Triso-coated $\mathrm{La}_{2} \mathrm{O}_{3}-$ $\mathrm{LaC}_{2}$ particles is plotted in Fig. 9; it is the same as that previously measured for Triso-coated $\mathrm{LaC}_{2}$ particles. ' However, in the Triso-coated $\mathrm{La}_{2} \mathrm{O}_{3}$ particles, the lanthanum has only reached the iLTI-buffer layer interface; therefore, no reaction with the SiC was observed.

\section{DISCUSSION}

As $\mathrm{UO}_{2}$ undergoes fission, the solid fission products separate principally into three phases: (1) oxides that are insoluble in the remaining $\mathrm{UO}_{2}$, (2) oxides that are in solid solution with the $\mathrm{UO}_{2}$, and (3) metallic inclusions. 15 Included among those oxides that can form insoluble phases are barium, strontium, and zirconium. In the presence of zirconium, the stable forms of these oxides are $\mathrm{BaZrO}_{3}$ and $\mathrm{SrZrO}_{3}$. However, the composition of the insoluble phase may change as the temperature is raised. Apparently, only $\mathrm{BaO}$ is insoluble in $\mathrm{UO}_{2}$ at all temperatures, while sro 


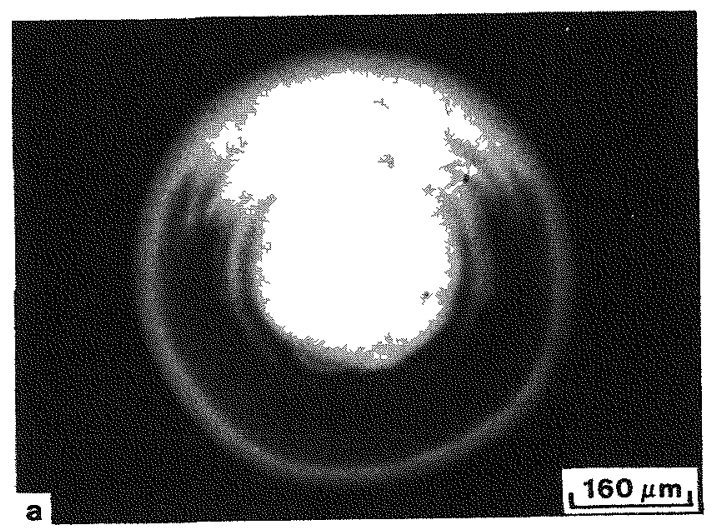

RADIOGRAPH 2100K - 41hr

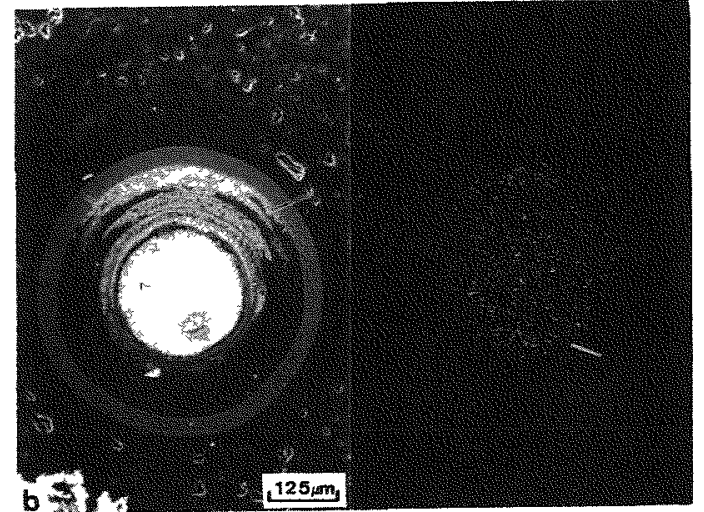

SECONDARY ELECTRON La La

IMAGE

$2100 \mathrm{~K}-41 \mathrm{hr}$

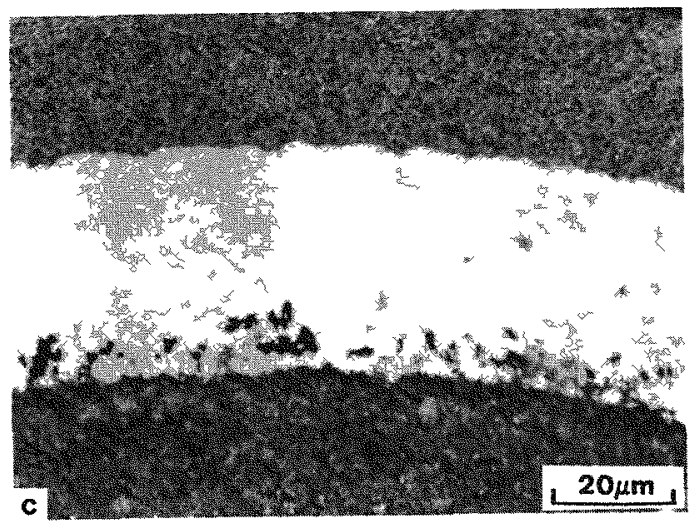

OPTICAL MICROGRAPH

1980K - 41hr

Fig. 8. Photographic results for Triso-coated $\mathrm{La}_{2} \mathrm{O}_{3}-\mathrm{LaC}_{2}$ particles after heat treatment at $1980 \mathrm{~K}$ or $2100 \mathrm{~K}$ for $41 \mathrm{hr}$ in a temperature gradient of $278 \mathrm{~K} / \mathrm{cm}$. Photographs are mounted so that the cold side of the particle faces the top of the page. Note in photographs a and $b$ that lanthanum has penetrated the ILTI on the cold side of the particle and has reached the SiC-iLTI interface. 


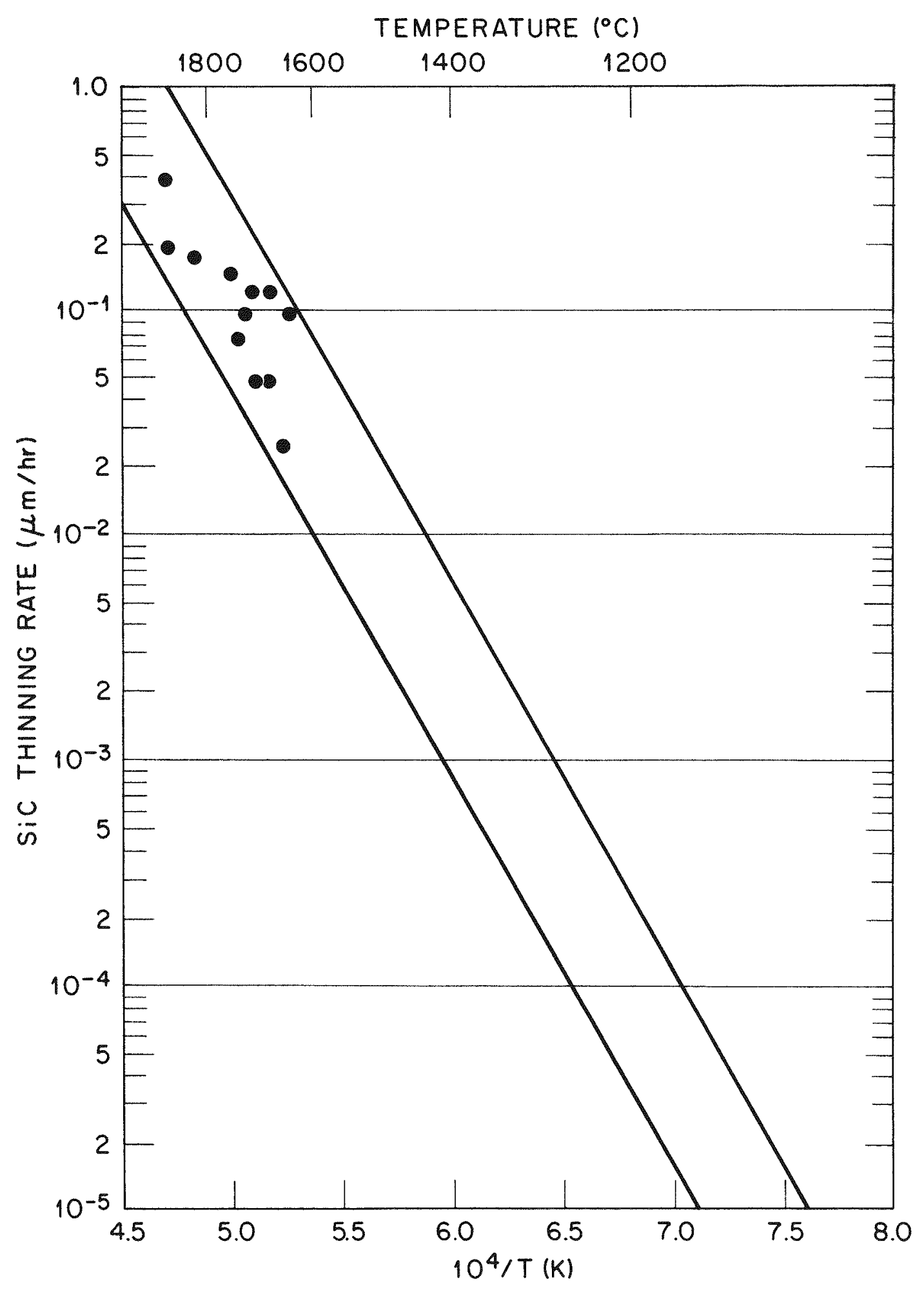

Fig. 9. Thinning rate of $\mathrm{SiC}$ for Triso-coated $\mathrm{La}_{2} \mathrm{O}_{3}-\mathrm{LaC}_{2}$ particles in a temperature gradient of $278 \mathrm{~K} / \mathrm{cm}$ vs reciprocal temperature. The solid lines are $90 \%$ confidence limits obtained by General Atomic Company from postirradiated, thermal-gradient annealing tests of Triso-coated $\mathrm{UC}_{2}$ (ref. 2). 
may be soluble to 20 at. \% above $1575 \mathrm{~K}$ (ref. 16) and $\mathrm{ZrO}_{2}$ is extensively soluble in $\mathrm{UO}_{2}$ above $1675 \mathrm{~K}$ (ref. 17). The insolubility of $\mathrm{BaO}$ and the apparent solution of Sro over the temperature range 1473 to $1973 \mathrm{~K}$ have been seen, in fact, in irradiated $\mathrm{UO}_{2} \mathrm{HTGR}$ fuel. 18

The $\mathrm{SrO}-\mathrm{ZrO}_{2}-\mathrm{UO}_{2}$ and $\mathrm{SrZrO}_{3}$ samples were used in an attempt to simulate the performance of these oxide fuel components. Strontium was chosen to simulate both strontium and barium because the literature indicates the possibility of strontium interactions with the coatings, whereas barium has never been identified in the interaction zones. Sufficient strontium was added to the $\mathrm{UO}_{2}$ sample to equal the yields of both elements. The proportion of zirconium to strontium plus barium shown in Table 1 exceeds unity; thus, even if zirconates formed, extra $\mathrm{ZrO}_{2}$ was available to form a solid solution in the $\mathrm{UO}_{2}$ matrix. The lack of interaction of this $\mathrm{SrO}-\mathrm{ZrO}_{2}-\mathrm{UO}_{2}$ sample with $\mathrm{SiC}$ (Fig. le) is not in agreement with postirradiation results reported by Brown et a1. ${ }^{3}$ Their approximated thinning rate (Fig. 2) falls closer to the data obtained from the defective $\mathrm{SrZrO}_{3}$ particles in this study.

Some elucidation of the behavior within the various oxide particles can be achieved by evaluation of thermodynamic data. A1though many exce1lent tabulations of free energy are available, it is frequently more convenient to use these data in the form of diagrams of the free energy of each equilibrium $\Delta G^{\circ}$ vs temperature T. Equilibrium data can be obtained from these diagrams (sometimes called E11ingham diagrams). ${ }^{19,20}$ Assumption of equilibrium in the present particles appears reasonable because of the extended times at very elevated temperatures. Even at the lower HTGR operational temperatures, equilibrium appears to have been achieved in irradiated $\mathrm{ThO}_{2}$ and $\mathrm{UO}_{2}-\mathrm{UC}_{2}$ fuels. ${ }^{21,22}$ In oxide and oxide-carbide fuels, the chemical potential of oxygen (or, simply, oxygen potential) is a fundamental parameter that defines many of the equilibrium chemical species; this is

$$
\mu_{\mathrm{O}_{2}}=\Delta \mathrm{G}^{\mathrm{o}}=-\mathrm{RT} \ln \left(\mathrm{p}_{\mathrm{O}_{2}} / \mathrm{p}_{\mathrm{O}_{2}}^{\mathrm{o}}\right)
$$

where 


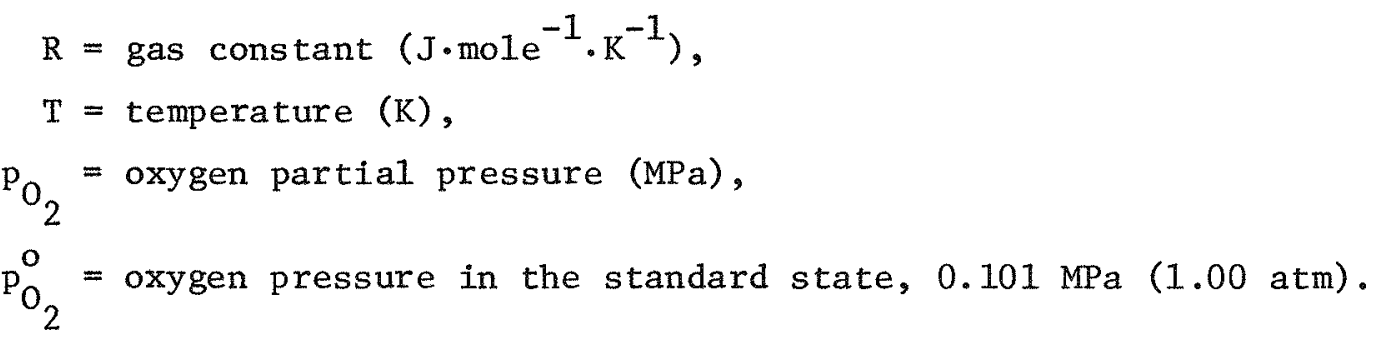

Figures 10 and 11 are Ellingham diagrams for the $\mathrm{Sr}-\mathrm{Zr}-\mathrm{O}-\mathrm{C}$ and $\mathrm{Ba}-$ $\mathrm{Zr}-\mathrm{O}-\mathrm{C}$ systems. These are divided into three regions. For example, in region $A$ of the strontium-containing system, where a significant $\mathrm{p}_{\mathrm{O}_{2}}$ exists, $\left\langle\mathrm{ZrO}_{2}\right\rangle,{ }^{*}\langle\mathrm{SrZrO}\rangle$, and $\langle\mathrm{C}\rangle$ are in equilibrium; the vapor pressures of $(\mathrm{Sr})$ and $(\mathrm{SrO})$ result from the equilibria $\left\langle\mathrm{SrZrO}_{3}\right\rangle z(\mathrm{Sr})+$ $\left(\mathrm{O}_{2}\right)+\left\langle\mathrm{ZrO}_{2}\right\rangle$ and $\left\langle\mathrm{SrZrO}_{3}\right\rangle \vec{z}(\mathrm{SrO})+\left\langle\mathrm{ZrO}_{2}\right\rangle$ respectively. In region $\mathrm{B}$, $\left\langle\mathrm{SrZrO}_{3}\right\rangle,\langle\mathrm{ZrC}\rangle$, and $\langle\mathrm{C}\rangle$ are in equilibrium, and the vapor pressures can be calculated from the equilibria $\left\langle\mathrm{SrZrO}_{3}\right\rangle+\langle\mathrm{C}\rangle \neq(\mathrm{Sr})+1.5\left(\mathrm{O}_{2}\right)+\langle\mathrm{ZrC}\rangle$ and $\left\langle\mathrm{SrZrO}_{3}\right\rangle+\langle\mathrm{C}\rangle \supsetneqq(\mathrm{SrO})+\left(\mathrm{O}_{2}\right)+\langle\mathrm{ZrC}\rangle$. In region $\mathrm{C}$, where an insignificant $\mathrm{p}_{\mathrm{O}_{2}}$ exists, $\left\langle\mathrm{SrC}_{2}\right\rangle,\langle\mathrm{ZrC}\rangle$, and $\langle\mathrm{C}\rangle$ are present, and the vapor pressure of $(\mathrm{Sr})$ is obtained from the equilibrium $\left\langle\mathrm{SrC}_{2}\right\rangle \supsetneqq(\mathrm{Sr})+2\langle\mathrm{C}\rangle$. The pressure of (SrO) in region $\mathrm{C}$ can be calculated from the equilibrium $\left\langle\mathrm{SrC}_{2}\right\rangle+$ $\left.1 / 2\left(\mathrm{O}_{2}\right) \gtrless(\mathrm{SrO})+2<\mathrm{C}\right\rangle$, but it is insignificant. If Sro went into solution in $\mathrm{UO}_{2}$ instead of forming $\mathrm{SrZrO}_{3}$, as it does above $1575 \mathrm{~K}$, the pressures of $(\mathrm{Sr})$ and ( $\mathrm{SrO}$ ) would be even less than those shown in Fig. 10, at a given oxygen potential and temperature, because its activity would be reduced. Measurements of CO content have shown that the oxygen potential in HTGR UO $\mathrm{U}_{2}$ fuel lies between -375 and $-500 \mathrm{~kJ} / \mathrm{mole}$ during reactor operation (Figs. 10, 11, and 12). ${ }^{21,23}$ According to the E11ingham plot in Fig. 10, the $(\mathrm{Sr})$ pressure was about $10^{-9} \mathrm{MPa}$ at $-500 \mathrm{~kJ} / \mathrm{mole}$ and $1560 \mathrm{~K}$, where the interaction shown in Fig. 3 was observed after $3528 \mathrm{hr}$. In every case the interactions occurred at the ends of cracks through the carbon layers, which resulted in direct exposure of the SiC to the gases originating from the $\mathrm{SrZrO}_{3}$ kernel. The cause of the cracks is unknown, but the chlorine leach test did show that some of the iLTI layers were defective; therefore, the cracks may have resulted from flaws in the iLTI layer. Interestingly, the interaction points are not temperature-gradient

\footnotetext{
Here, $<>$ indicates a solid species and ( ) indicates a gaseous
} 


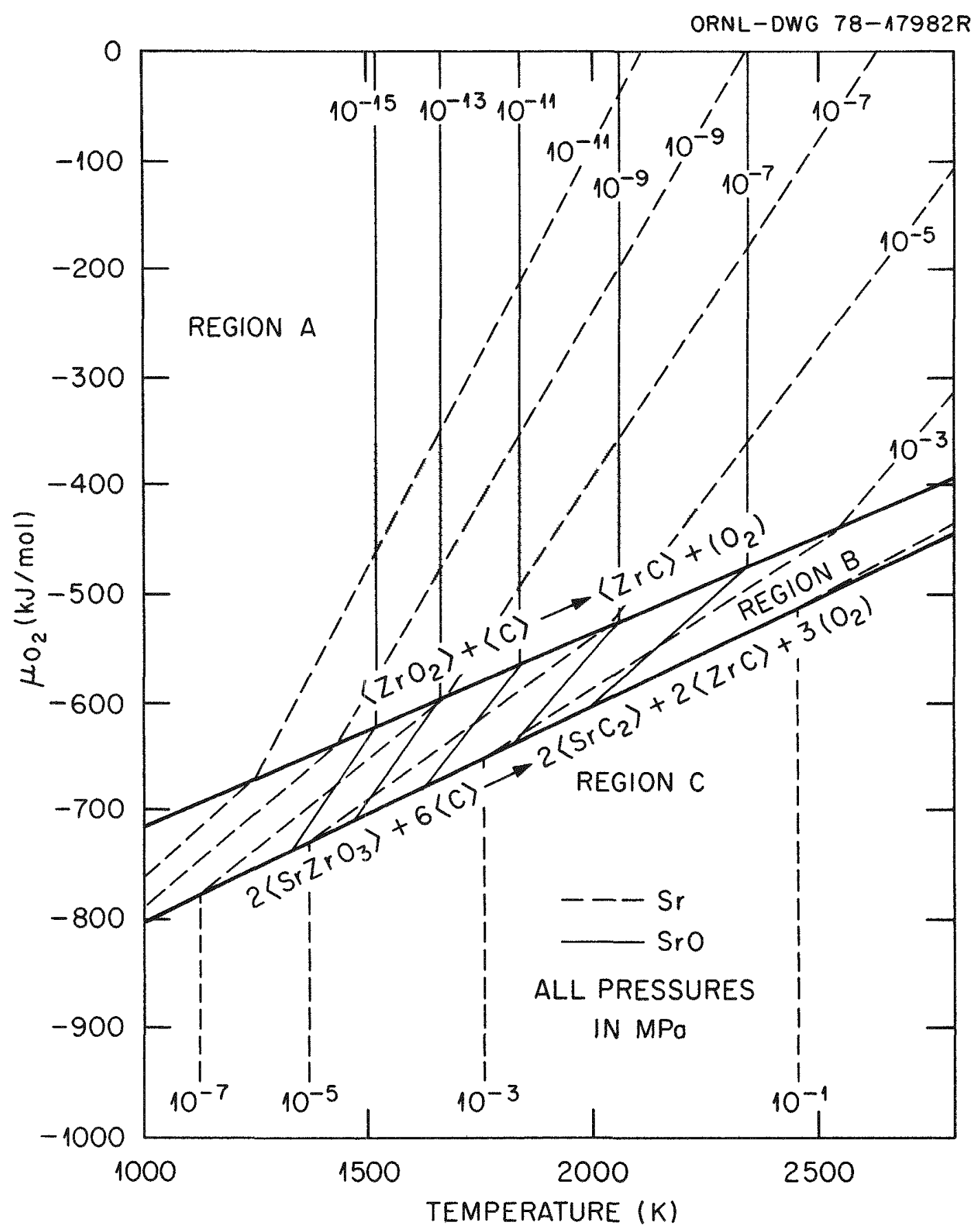

Fig. 10. Ellingham diagram of the Sr-Zr-O-C system. Shaded area is the oxygen potential measured in irradiated $\mathrm{UO}_{2}$ fuel particles (ref. 23). 


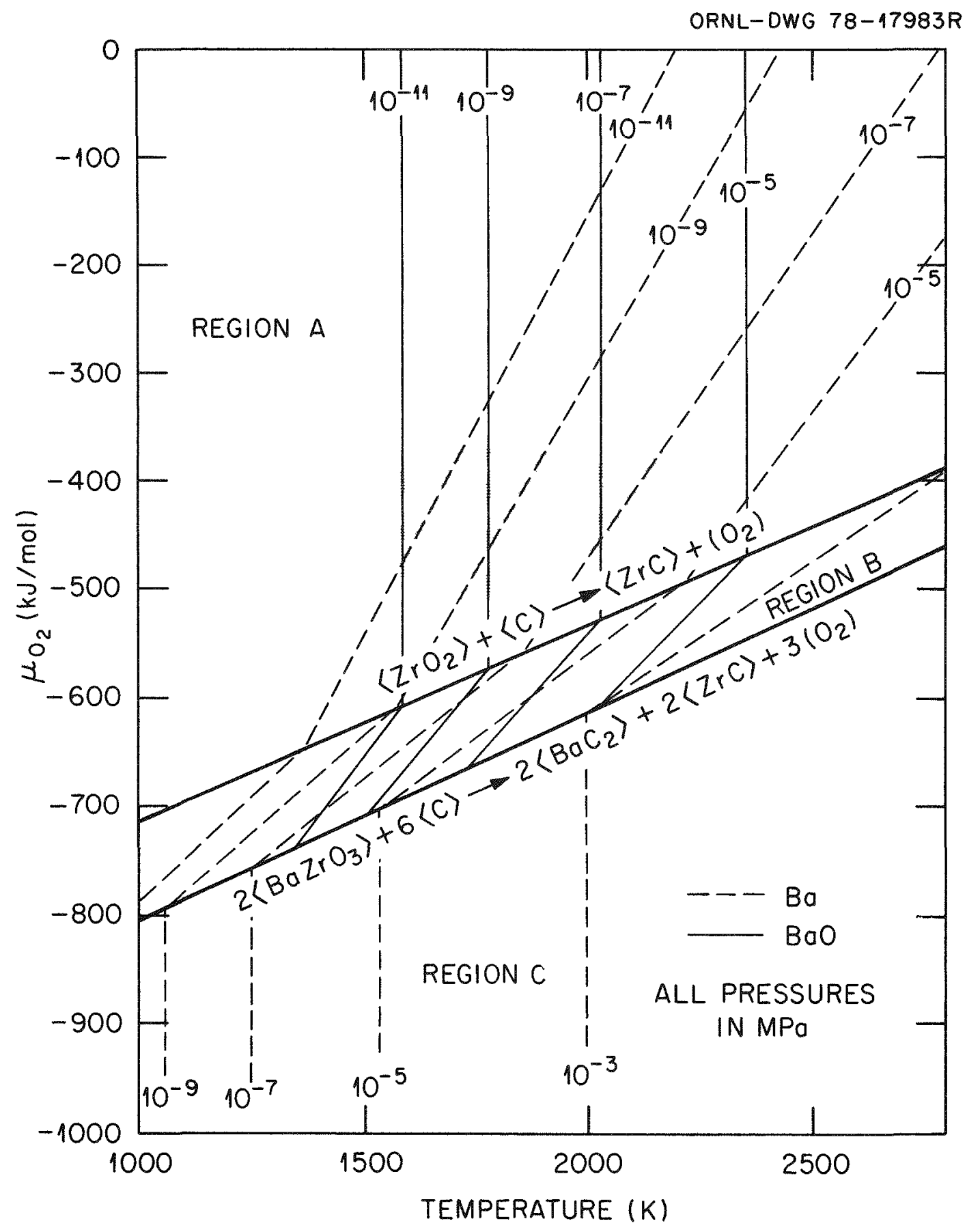

Fig. 11. Ellingham diagram of the Ba-Zr-O-C system. Shaded area is the oxygen potential measured in irradiated $\mathrm{UO}_{2}$ fuel particles (ref. 23). 


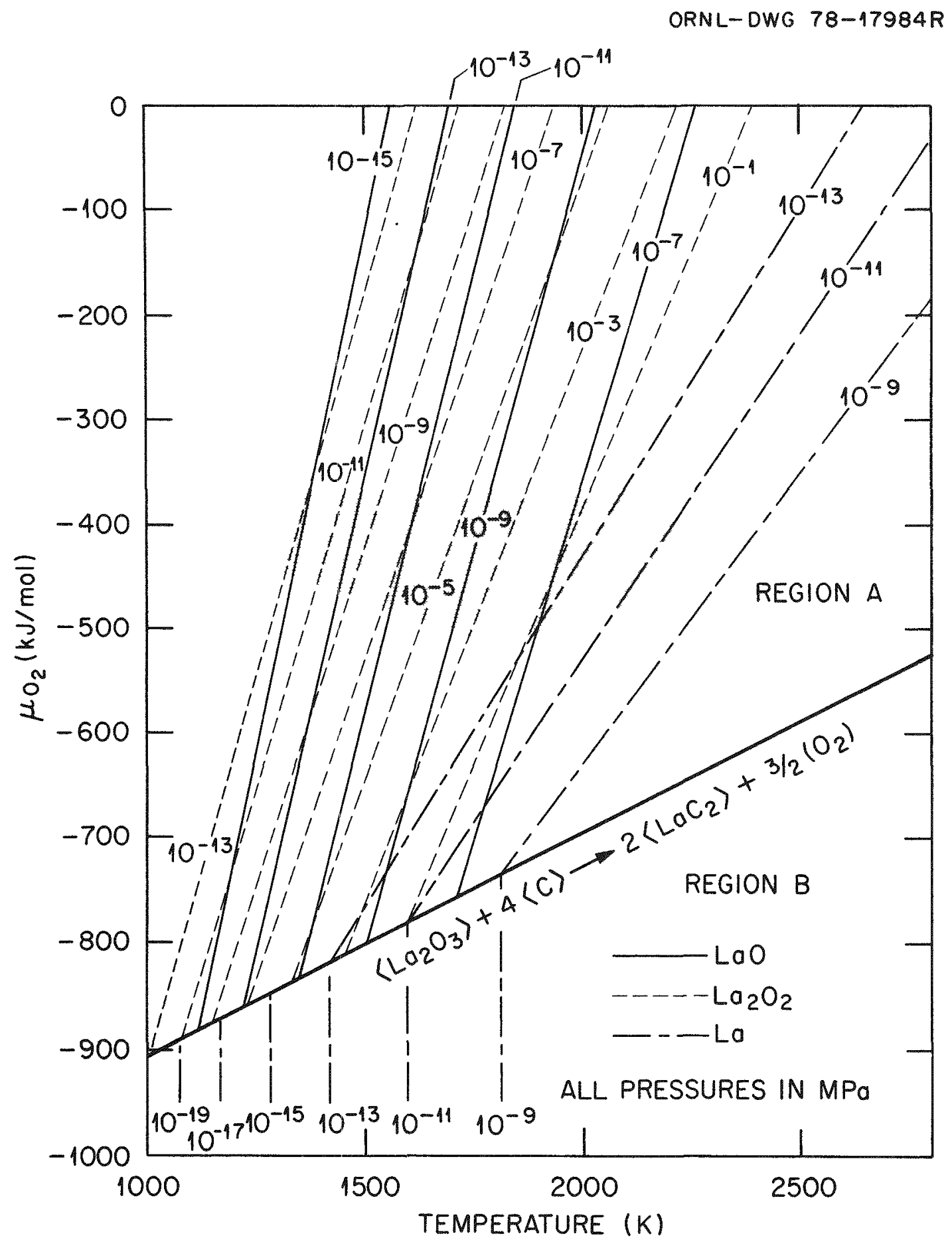

Fig. 12. E11ingham diagram of the La-O-C system, Shaded area is the oxygen potential measured in irradiated $\mathrm{UO}_{2}$ fuel particles (ref. 23). 
oriented; rather, they occur wherever the cracks intercept the SiC layer. In the Triso-coated Sro- $\mathrm{ZrO}_{2}-\mathrm{UO}_{2}$ particles heated at $2200 \mathrm{~K}$ for $94 \mathrm{hr}$, the iLTI layers seemed impermeable to ( $S r)$ because we saw no interaction. The (Sr) pressure inside these particles was about $10^{-5} \mathrm{MPa}$ (Fig. 10). Earlier work on the $\mathrm{UO}_{2}-\mathrm{C}-\mathrm{N}_{2}$ reaction at $1975 \mathrm{~K}$ demonstrated that a (HCN) pressure of $10^{-6} \mathrm{MPa}$ was sufficient to transport substantial amounts of carbon across a $0.02-\mathrm{cm}$ gap. ${ }^{24}$ Thus, the (Sr) pressure should be adequate for transport. Because the Sr-SiC interaction reported by Brown et al. 3 falls closer to our $\mathrm{SrZrO}_{3}$ data than to our $\mathrm{SrO}-\mathrm{ZrO}_{2}-\mathrm{UO}_{2}$ data, it may be that their observed Sr-SiC interaction was due to a permeable or defective iLTI layer in the Triso-coated $\mathrm{vO}_{2}$ fuel. Further efforts to verify this conclusion will be undertaken. A second set of Triso-coated particles containing $\mathrm{SrZrO}_{3}$ will be formed, heat-treated, and examined for Sr-SiC interaction.

Comparing Figs, 10 and 11 shows that a (Ba) pressure equivalent to that for $(\mathrm{Sr})$ is reached only at a higher temperature at a given oxygen potential, $\mu_{\mathrm{O}_{2}}$. Therefore, as the temperature is raised, ( $\mathrm{Sr}$ ) probably could react with $\mathrm{SiC}$ before $(\mathrm{Ba})$.

The oxides $\mathrm{La}_{2} \mathrm{O}_{3}, \mathrm{Nd}_{2} \mathrm{O}_{3}$, and $\mathrm{Sm}_{2} \mathrm{O}_{3}$ form solid solutions with $\mathrm{UO}_{2}$, as do all rare earth oxides. Because there was no evidence of SiC interaction in the particles containing $\mathrm{La}_{2} \mathrm{O}_{3}, \mathrm{Nd}_{2} \mathrm{O}_{3}$, or $\mathrm{Sm}_{2} \mathrm{O}_{3}$ kernels, it is concluded that the second phase, the rare earth- $\mathrm{UO}_{2}$ solid solution phase, will not interact with the $\mathrm{SiC}$ coating layer. However, $\left\langle\mathrm{La}_{2} \mathrm{O}_{3}\right\rangle$ will vaporize and form the gas $\left(\mathrm{La}_{2} \mathrm{O}_{2}\right)$. Thermodynamic data for $\left(\mathrm{La}_{2} \mathrm{O}_{2}\right)^{25}$ was used to calculate a pressure of about $10^{-1} \mathrm{MPa}$ at $2000 \mathrm{~K}$ and at an oxygen potential, $\mu_{\mathrm{O}_{2}}$, of $-500 \mathrm{~kJ} / \mathrm{mole}$, as seen in Fig. 12. The transfer of lanthanum into the carbon buffer layer (Fig. 4b and d) is most likely the result of this gaseous species. Unlike ( $\mathrm{La}),\left(\mathrm{La}_{2} \mathrm{O}_{2}\right)$ is apparently unable to diffuse through the iLTI layer. Although the equivalent gaseous species for the other rare earths are not listed in the thermodynamic tables, it is quite likely that each has such a gaseous form because of similar chemistry. This assumption may explain why a variety of rare earths were observed to have distributed themselves quite widely within 0 and $15 \%$ converted WAR fuel particles irradiated to $85 \%$ FIMA in HRB-9. 26,27 
The lack of interaction with $\mathrm{SiC}$ in the $\mathrm{Nd}_{2} \mathrm{O}_{3}-\mathrm{UO}_{2}-\mathrm{UC}_{2}$ particles implies that an irradiated $\mathrm{UO}_{2}-\mathrm{UC}_{2}$ fuel will not result in SiC attack by the rare earths. In the mixed fuel, all rare earth fission products will exist as solid oxides as long as the initial $\mathrm{UC}_{2}$ content is kept below a specified maximum value. ${ }^{22}$ The observation that no SiC interaction occurs in a Triso-coated $\mathrm{La}_{2} \mathrm{O}_{3}$ particle, while the rate of $\mathrm{SiC}$ thinning in a Triso-coated $\mathrm{La}_{2} \mathrm{O}_{3}-\mathrm{LaC}_{2}$ particle is the same as was seen in a Triso-coated $\mathrm{LaC}_{2}$ particle (Fig. 8), verifies our earlier conclusion that the presence of rare earth carbides is necessary for the rare earth-SiC reaction mechanism. ${ }^{7}$ Conversely, the rare earth oxides, either in solid or gaseous form, are not involved in the reaction of rare earths with SiC.

\section{CONCLUSIONS}

The following four conclusions are drawn from this study:

1. We observed strontium-SiC interaction in strontium- and zirconium-containing Triso-coated oxide particles only if there was direct contact between the strontium gas $[(\mathrm{Sr})]$ and the SiC. Such conditions were achieved in particles with defective ilTI layers. No reaction occurred (even at $2200 \mathrm{~K}$ ) when the iLTI layers were impermeable. The approximated SiC thinning rate observed by Brown et a1. ${ }^{3}$ in irradiated Triso-coated $\mathrm{UO}_{2}$, and attributed by them to be a strontium-SiC interaction, falls close to the thinning rate we obtained in strontium- and zirconiumbearing Triso-coated oxide particles with defective iLTI layers. It is possible that their strontium-SiC interaction was the result of a permeable or defective iLTI layer in the Triso-coated $\mathrm{VO}_{2}$ fuel.

2. No SiC interactions were observed in Triso-coated $\mathrm{Sm}_{2} \mathrm{O}_{3}, \mathrm{La}_{2} \mathrm{O}_{3}$, $\mathrm{Nd}_{2} \mathrm{O}_{3}-\mathrm{UO}_{2}$, or $\mathrm{Nd}_{2} \mathrm{O}_{3}-\mathrm{UO}_{2}-\mathrm{UC}_{2}$, even at extreme temperatures. Each of these particles has a calculated $\left(\mathrm{RE}_{2} \mathrm{O}_{2}\right)$ pressure of about $10^{-1} \mathrm{MPa}$ at $2000 \mathrm{~K}$. Even so, these gases apparently cannot diffuse through the iLTI layer and interact with the SiC; however, they do result in some redistribution of rare earths within the buffer layer.

3. The SiC layer thins at the same rate in Triso-coated $\mathrm{La}_{2} \mathrm{O}_{3}-\mathrm{LaC}_{2}$ particles as in Triso-coated $\mathrm{LaC}_{2}$ particles under the same heating 
conditions. Apparently, rare earth carbides will react with SiC, but rare earth oxides will not.

4. As long as some $\mathrm{UO}_{2}$ remains during irradiation of $\mathrm{UO}_{2}-\mathrm{UC}_{2}$ fuel mix, the rare earth fission products will exist only as oxides, and there will be no Sic-rare earth interaction.

\section{ACKNOWLEDGMENTS}

The authors wish to thank the following people for their contributions to this study: P. A. Kuehn of the Solid State Division, J. H. Shaffer of the Chemical Technology Division, and G. W. Weber and C. S. Morgan of the Metals and Ceramics Division for helping to prepare the kernel compositions; J M Robbins and C. Hamby, Jr., of the Metals and Ceramics Division for Triso-coating the kernels; and O. B. Cavin, W. J. Mason, R. S. Crouse, N. W. Atchley, and J. W. Nave of the Metals and Ceramics Division and C. A. Culpepper of the Solid State Division for their assistance in examining the particles. Betty Drake and Kyle Johnson helped prepare the manuscript.

\section{REFERENCES}

1. T. D. Gulden and H. Nickel, "Preface: Coated Particle Fuels," Nuc1. Technol. 35, 206 (1977).

2. M. T. Morgan and A. P. Malinauskas, "Cesium Release and Transport in Biso-Coated Fuel Particles," Nuc1. Technol. 35, 457 (1977).

3. P. E. Brown et al., Metal Fission Product Behaviour in HTR UO2Coated Particle Fue1, AERE-R8065 (June 1975).

4. D. P. Harmon and C. B. Scott, Development and Irradiation Performance of LHTGR Fue1, GA-A13173, pp. 24, 25, and 115 (October 1975).

5. F. J. Homan and E. L. Long, Jr., Irradiation Performance of HTGR Recycle Fissile Fue1, ORNL/TM-5502 (August 1976).

6. B. F. Rider and M. E. Meek, Compilation of Fission Product Yields, NEDO-12154-2 (July 1977). 
7. R. L. Pearson and T. B. Lindemer, "The Interaction of $\mathrm{LaC}_{2}$ and $\mathrm{NdC}_{2}$ with SiC in HTGR Particles," in Proc. of the ANS Thermal Reactor Safety Meeting, July 31-Aug。 4, 1977, Sun Valley, Idaho.

8. P. A. Keuhn, ORNL, personal communication, January 1979.

9. P. A. Haas, HTGR Fuel Development: Use of $\mathrm{UO}_{3}$ to Load Cation Exchange Resin for Microsphere Preparation, ORNL/TM-3817 (September 1972).

10. J. H. Shaffer and C. W. Greene, The Reaction of Uranyl Nitrate Solutions with Carboxylic Acid Cation Exchange Resin at 30, 40, and $50^{\circ} \mathrm{C}$, ORNL/TM-6611 (January 1979).

11. G. W. Weber, R. L. Beatty, and V. J. Tennery, Properties of Carbonized and Converted Uranium-Loaded Weak-Acid Resins, ORNL-5201 (February 1977).

12. D. E. LaValle et a1., "The Determination of Defective Particle Fraction in High Temperature Gas-Cooled Reactor Fuels," Nuc1. Technol. 33, 290 (1977).

13. T. B. Lindemer and R. L. Pearson, "Kernel Migration for HTGR Fuels from the System Th-U-Pu-C-O-N," J. Am. Ceram. Soc. $60(1-2), 5-14$ (1977).

14. R. L. Pearson and T. B. Lindemer, Uranium Loss from Biso-Coated WeakAcid Resin HTGR Fue1, ORNL/TM-5552 (February 1977).

15. D. R. Olander, Fundamental Aspects of Nuclear Reactor Fuel Elements, TID-26711-P1, Technical Information Center, 1976, pp. 172-98.

16. C. Ke11er, "Lanthanide and Actinide Mixed Oxide Systems of FaceCentered Cubic Symmetry," pp. 1-38 in Inorganic Chemistry-Series Two, vol. 7, K. W. Bagna11, Ed., Butterworths, London, 1975.

17. K. A. Romberger et al., "Phase Equilibrium Studies in the $\mathrm{UO}_{2}-\mathrm{ZrO}_{2}$ System," J. Inorg. Nuc1. Chem. 29, 1619-30 (1967).

18. C. A. Friskney and K. A. Simpson, "The Behaviour of Fission-Product Barium and Strontium in Irradiated $\mathrm{UO}_{2}, " \mathrm{~J}$. Nucl. Mater. 57, 121-22 (1975). 
19. T. B. Reed, Free Energy of Formation of Binary Compounds, MIT Press, Cambridge, 1971.

20. F. D. Richardson and J. H. E. Jeffes, "The Thermodynamics of Substances of Interest in Iron and Steel Making from $0^{\circ} \mathrm{C}$ to $2400^{\circ} \mathrm{C}, "$ J. Iron Stee1 Inst. 160, 261 (1948).

21. T. B. Lindemer, "Measurement and Interpretation of $\mathrm{CO}$ and $\mathrm{Kr}+\mathrm{Xe}$ in Irradiated Tho ${ }_{2}$-Containing HTGR Fuel Particles," J. Am. Ceram. Soc. $60(9-10), 409-16$ (1977).

22. F. J. Homan et a1,, "Stoichiometric Effects on Performance of HighTemperature Gas-Cooled Reactor Fuels from the U-C-0 System," Nuc1. Techno1. 35, 428 (1977).

23. T. B. Lindemer and H. J. de Nordwa11, An Analysis of Chemica1 Failure of Coated $\mathrm{UO}_{2}$ and Other Oxide Fuels in the High-Temperature Gas-Cooled Reactor, ORNL-4926 (January 1974).

24. T. B. Lindemer, "Kinetics of the $\mathrm{UO}_{2}-\mathrm{C}-\mathrm{N}_{2}$ Reaction at $1700^{\circ} \mathrm{C}$," J. Am. Ceram. Soc. 55(12), 601-5 (1972).

25. R. H. Schumm et al., "Selected Values of Chemical Thermodynamic Properties, Tables for the Lanthanide (Rare Earth) Elements," NBS Technical Note 270-7, National Bureau of Standards, Washington, D.C., 1973.

26. F. J. Homan et a1., Irradiation Performance of HTGR Fue1 Rods in HFIR Experiments HRB-9 and -10, ORNL-5254 (Apri1 1978).

27. T. N. Tiegs and T. J. Henson, Fission Product Behavior in HTGR Fue1 Particles Made from Weak-Acid Resins, ORNL/TM-6780 (Apri1 1979). 
ORNL/TM-6741

Dist. Category UC-77

INTERNAL DISTRIBUTION

\author{
1. R. L. Beatty \\ 2. J. A. Carpenter, Jr. \\ 3. R. S. Crouse \\ 4. F. J. Homan \\ 5-14. P. R. Kasten \\ 15. W. J. Lackey \\ 16. R. J. Lauf \\ 17. K. H. Lin \\ 18-27. T. B. Lindemer \\ 28. E. L. Long, Jr. \\ 29. A. P. Malinauskas \\ 30. K. J. Notz
}

\author{
31-40. R. L. Pearson \\ 41. M. G. Stewart \\ 42. D. P. Stinton \\ 43. V. J. Tennery \\ 44. S. M. Tiegs \\ 45. R. P. Wichner \\ 46-47. Central Research Library \\ 48-52. Laboratory Records \\ 53. Laboratory Records, R.C. \\ 54. ORNL-Y-12 Technical Library \\ Document Reference Section \\ 55. ORNL Patent Section
}

EXTERNAL DISTRIBUTION

56. Office of Assistant Manager, Energy Research and Development, DOE-ORO

57. Director, Nuclear Research and Development, DOE-ORO

58-59. Director, Division of Nuclear Power Development, DOE, Washington, DC 20545

60. Senior Program Coordinator, San-Development, San Diego Area Office, P. O. Box 81325, San Diego, CA 92138

61. Manager, San Francisco Operations Office, DOE, 1333 Broadway, Wells Fargo Building, Oakland, CA 94612

62-237. Given distribution as shown in TID-4500 under Gas-Cooled Reactor Technology category 